\title{
Obsahová analýza v pedagogickom výskume: Pohl'ad na jej súčasné podoby
}

\author{
Peter Gavora \\ Univerzita Tomáše Bati ve Zlíně, Fakulta humanitních studií, Centrum výzkumu
}

Redakci zasláno 7. 1. 2015 / upravená verze obdržena 28. 3. 2015 /

k uveřejnění přijato 30. 3. 2015

\begin{abstract}
Abstrakt: Množstvo metodologických vplyvov zapríčinilo, že obsahová analýza nadobudla rôzne podoby a že jej súčasný stav je dost' komplikovaný. Ciel'om tejto štúdie je opísat' jej súčasné podoby opierajúc sa o zdôvodnený výber literatúry. Rôzne podoby obsahovej analýzy sú $\mathrm{v}$ jednotlivých kapitolkách štúdie postupne opísané podla tzv. konštitučných komponentov. Týchto komponentov je šest': typ analyzovaného obsahu, výskumná vzorka, híbka analýzy, smer postupu, druh kontroly kódovania a forma vyjadrenia výsledku výskumu. $V$ štúdii budú podrobne charakterizované rôzne náplne týchto komponentov. Výsledkom štúdie je zistenie, aké konkrétne konfigurácie uvedených náplní existujú a v akom sú vzt'ahu. Celkový záver štúdie vedie k potvrdeniu, že rozdelenie obsahovej analýzy na kvantitatívnu a kvalitatívnu je nepresné, a preto nefunkčné a že lepšie je hodnotit' podobu obsahovej analýzy v konkrétnej výskumnej štúdii podl’a špecifických náplní jej konštitučných komponentov.
\end{abstract}

Klúčové slová: obsahová analýza, text, manifestný obsah, latentný obsah, induktívny postup, deduktívny postup, reliabilita, kredibilita

Obsahová analýza predstavuje už dlhé obdobie štandardnú metódu pedagogického výskumu zameranú na vyhodnotenie a interpretáciu obsahu textov. Bola spol'ahlivo aplikovaná v nespočetnom množstve výskumov, ktoré sa sústredili na rôzne typy a formy textov a preukázala pri nich vysokú funkčnost'.

Od čias vzniku obsahovej analýzy v pät'desiatych rokoch minulého storočia sa svet textu zmenil. Pribudli nové žánre, iné sa modifikovali, a zmenili sa aj obsahy. Objavili sa nové témy a idey. Markantným spôsobom stúplo množstvo vytváraných a produkovaných textov. Rýchlejšia, pružnejšia a azda aj lacnejšia technika tlače umožnila chrlit' tlačené texty. Produkcia študijných materiálov, učebníc, kníh a odborných časopisov rapídne narástla a tento trend sa zrejme nezastaví. Vývoj priniesol elektronizáciu textov, čo umožnilo nielen ich rýchlu tvorbu, ale aj ich pružné spracovávanie a analýzu 
vo výskume. Papier prestal byt' jediným a už vôbec nie najčastejším nosičom obsahu. Dnes sú predmetom obsahovej analýzy aj webové stránky, film a obrázky.

Obsahová analýza bola pôvodne len kvantitatívnou výskumnou metódou. Definícia obsahovej analýzy B. Berelsona, ktorá sa považuje za zakladatel'skú, ju vymedzila ako výskumnú techniku na objektívny a systematický kvantitatívny opis manifestného obsahu komunikátu (communication; Berelson, 1952, cit. podl'a Krippendorffa, 2004, s. 18). Ciel'om obsahovej analýzy je podla tejto koncepcie získat' kvantitatívny opis vybranej vzorky komunikátov. Dôraz sa kladie na presnost' a spolahlivost' postupov - podobne, ako je to pri každej výskumnej metóde v kvantitatívnom výskume - dotazníku, škálovaní, experimente, sociometrii, štruktúrovanom pozorovaní apod. Z tohto dôvodu sa pri kvantitatívnej obsahovej analýze venuje vel'ká starostlivost' správnemu výberu vzorky, vol'be kodérov a ich výcviku, preveruje sa objektivita a reliabilita postupov atd'.

Zásadným momentom, ktorý ovplyvnil d’alší vývoj obsahovej analýzy, bol nástup kvalitatívnej metodológie výskumu. Tá vychádza z odlišného chápania reality a poznávania sveta, prináša iné funkcie výskumu, odlišné výskumné ciele a postupy. Obsahová analýza sa tomuto metodologickému prúdu nemohla vyhnút'. Otvorila sa mu a obohatila sa ním (Schreier, 2012; Mayring, 2014). Výsledkom je, že dnes stoja popri sebe dve filozoficky a metodologicky odlišné koncepcie obsahovej analýzy, kvantitatívna a kvalitatívna. Navyše, postupne narastajúca liberalizácia metodológie výskumu umožnila, že kvantitatívny a kvalitatívny prúd metodológie sa už nechápu ako dva súperiace tábory, ale ako priatel'ské strany, ktoré si vo výskume môžu vzájomne vypomáhat'. Tým sa však situácia stala neprehl'adnou. Dochádza k premiešavaniu prúdov, čo spôsobuje koncepčné zahmlievanie, a to zase vyvoláva mnohé metodologické otázky. Neprehl'adná situácia vyústila do záveru, že obsahová analýza nadobudla rozpoltenú identitu (Dvořáková, 2010, s. 99). Otázkou už nie je len z čoho sa obsahová analýza skladá a ako sa uskutočňuje, ale čo vlastne obsahovou analýzou je, resp. nie je.

\section{Zámer a ciel’ štúdie}

Zámerom tejto štúdie je charakterizovat' súčasné podoby obsahovej analýzy opierajúc sa o relevantnú metodologickú literatúru. Cielom je ukázat', že napriek komplikovanej situácii vyznačujúcej sa nejasnost'ou a často 
protichodnými tendenciami je možné vytvorit' zrozumitel'nú a harmonickú prehladovú schému, ktorá zosobňuje všetky podstatné komponenty obsahovej analýzy v jej rôznych náplniach. Výsledným produktom tejto štúdie, ktorý je umiestnený na jej konci, je tento prehl'adový systém a jeho interpretácia.

Postup, ktorý použijeme, spočíva v rozklade obsahovej analýzy na jej konštitučné komponenty. Potom budeme skúmat', ako sa tieto komponenty napíňajú v dielach relevantných autorov. Týchto komponentov je šest':

1. typ analyzovaného obsahu;

2. vol'ba výskumnej vzorky;

3. vol'ba híbky analýzy;

4. smer postupu pri analýze;

5. druh kontroly analýzy dát;

6. forma vyjadrenia výsledku výskumu.

Naším zámerom nie je opísat' obsahovú analýzu v podobe dvoch kontrastných variantov, kvantitatívneho a kvalitatívneho, ako sa to často traduje (napr. Elo \& Kyngäs, 2008; Devi, 2009), ale hladat' rôzne náplne jej konštitučných komponentov a ich rôzne konfigurácie. Domnievame sa, že tento postup je jemnejší, a preto užitočnejší ako bipolárne delenie na dva metodologické prúdy. Čitatel' preto nenájde v štúdii tradičnú porovnávaciu tabul'ku kvantitatívnej a kvalitatívnej obsahovej analýzy. Štúdia vyústi do členitej schémy, ktorá bude charakterizovat' viaceré varianty obsahovej analýzy.

Relevantné diela, o ktoré sa budeme opierat', sú predovšetkým vel'ké monografie Neuendorfovej (2002) a Krippendorffa (2004), dalej kapitola o obsahovej analýze v monografii Berga (1995), monografia Guesta, MacQueenovej a Nameyovej (2012) a štúdia Whiteovej a Marshovej (2006). Budeme tiež vychádzat' z archetypálnych diel Berelsona (1952) a Holstiho (1969). Okrem toho použijeme podl'a potreby samozrejme i d'alšiu literatúru, napr. monografie nemeckých autorov Schreierovej (2012) a Mayringa (2014) venované kvalitatívnej obsahovej analýze. Tieto diela boli vybrané na základe odbornej relevantnosti, citovanosti a vydavatel'a. Všetky monografické diela, s výnimkou práce Mayringa, publikované po roku 2000, boli vydané v prestížnom vydavatel'stve SAGE. 
Konštitučné komponenty spomenuté vyššie boli extrahované z diel uvedeného súboru autorov, navrhnutý systém preto môžeme považovat' za dobre „zakotvený“ v relevantnej literatúre.

\section{Výskumná metóda, technika alebo výskumná koncepcia?}

Na začiatku je potrebné odpovedat' na otázku, čo sa chápe pod slovom „analýza“ v spojení so slovom „obsahová“. Odpoved' nie je l'ahká. Berelson (1952) vymedzil obsahovú analýzu ako výskumnú techniku, podobne ako Krippendorff (2004, s. 18), ale on ju tiež označil za výskumný nástroj i výskumnú metódu. Neuendorfová (2002) na rôznych miestach svojej knihy hovorí o obsahovej analýze ako o technike, metóde i metodológii. Terminologická nejednotnost' naznačuje koncepčný zmätok.

Pokúsime sa z tejto situácie navrhnút' určité východisko. Každý výskum pracuje s dátami, ktoré musí výskumník analyzovat'. Predmetom analýzy je obsah týchto dát. Pritom môže použit' najrôznejšie výskumné metódy na ich získanie, napríklad test, dotazník, interview alebo pozorovanie. Môže sa prikláňat' $\mathrm{k}$ akémukol'vek metodologickému smeru - zakotvenej teórii, diskurzívnej analýze, konverzačnej analýze atd'. Obsahová analýza je prítomná v každom výskume. Výskum je založený na dátach a tieto dáta zosobňujú určitý obsah. Úlohou výskumníka je podrobit' dáta analýze, čiže analyzovat' určitý obsah.

Takéto široké vymedzenie obsahovej analýzy by viedlo k jej rozplynutiu sa do metodologickej hmly, čiže k jej devalvácii. Jej poňatie je preto nevyhnutné zúžit'. V tejto štúdii budeme uvažovat' o obsahovej analýze ako o výskumnej koncepcii, resp. dizajne. Ten musí spĺňat' nasledujúce kritériá:

1. Výskumné otázky, resp. hypotézy sú viazané na použitie obsahovej analýzy.

2. Je presne vymedzený súbor textov pre analýzu. Súbor je dostatočne silný na získanie relevantných odpovedí na výskumné otázky.

3. Je určená jednotka analýzy (konkrétny jav, pojem, téma, premenná).

4. Je vytvorený systém kódov, ich definície a pravidlá ich používania.

5. Proces kódovania je kontrolovaný bud' vo forme zistenia reliability, alebo dôkazu kredibility.

6. Výskumné zistenia vychádzajú z kódovania podla bodu 5 . 
Príkladom dobre naprojektovanej a zrealizovanej obsahovej analýzy v tomto chápaní je štúdia Adamsa, Walkera a O’Connella (2011).

Autori uskutočnili výskum, uverejnený pod názvom Neviditel'ní alebo angažovaní otcovia? s podtitulom Obsahová analýza reprezentácie rodičov v detských obrázkových knihách vydaných v Spojenom královstve. Cielom bolo analyzovat' knižky pre najmladšie deti (0-5 rokov) a dokázat', že genderová stereotypizácia sa exponuje detom už v ranom období, čo má dôležitý socializačný dopad na dieta. Výskum testoval sedem hypotéz: (1) otcovia sú zobrazovaní menej často ako matky, (2) sú menej často zobrazovaní doma, (3) sú zobrazovaní menej často pri detoch, (4) sú častejšie zobrazovaní sami, (5) menej často sú zobrazovaní ako dotýkajúci sa detí, (6) menej vyjadrujú svoje emócie ako matky, (7) sú menej často zobrazovaní pri domácich prácach a starostlivosti o deti ako matky. Populáciu kníh tvorili bestsellery vydané v Spojenom královstve v roku 2008 pre uvedenú vekovú skupinu a pozostávali zo 750 kníh. Z nich sa vybrali všetky knihy, ktoré explicitne zobrazovali rodičov. Týchto kníh bolo 160 . Z nich sa náhodným spôsobom vybralo 60 kníh (výskumná vzorka). Jednotkou analýzy bolo zobrazenie rodiča v knihe $\mathrm{v}$ danom prostredí a $\mathrm{v}$ danej aktivite, a to $\mathrm{v}$ texte, na obrázku, alebo obidvomi spôsobmi. Na účel analýzy autori vytvorili kódovú schému, ktorá pozostávala zo 140 kategórií. Každý zistený výskyt predstavoval jeden kód (záznam v kódovacom hárku). Autori kontrolovali reliabilitu kódovania kategórií pomocou kódovania dvomi kodérmi, ktorí nezávisle nakódovali všetkých 60 kníh výskumnej vzorky (koeficient zhody bol 0,96, čo predstavuje vysokú mieru súladu). To znamená, že kódový systém fungoval spolahlivo a kódovanie bolo presné. Dáta boli vyjadrené $\mathrm{v}$ podobe frekvencie výskytu $\mathrm{v}$ jednotlivých kategóriách.

Tento výskum predstavoval typický predmet analýzy obsahu - knižné texty. Pedagogický výskum sa však často zameriava i na texty, ktoré vznikli ako produkcia výskumných subjektov, pričom výskumnou metódou boli napríklad reflektívne písanie, tematické písanie, denníky učitel'ov. Predmetom obsahovej analýzy sú aj transkripty (prepisy) neštruktúrovaných alebo pološtruktúrovaných interview (napr. Hloušková, 2013; Pravdová, 2013), interview s fókusovými skupinami (napr. Kostková, 2013), videoštúdií (Hübelová, 2009; Najvar et al., 2011) apod. Tieto výskumy naplňujú uvedené kritériá obsahovej analýzy odlišným spôsobom, a to tak, aby boli v súlade s kánonmi metodológie kvalitatívneho výskumu.

Výskum B. Pravdovej (2013) sa zameral na sebapoňatie učitela, ktoré je jedným z činitel'ov ovplyvňujúcich výkon učitelskej profesie. Pozitívne sebapoňatie je predpokladom úspešného výkonu, negatívne sebapoňatie výkon znižuje. Výskum bol zameraný na formujúce sa sebapoňatie, ako ho prejavovala jedna študentka 
učitelstva. Boli formulované tri výskumné otázky: (1) Ktoré aspekty profesijného sebapoňatia študentky v poslednom ročníku štúdia sú dominantné? (2) Ako možno opísat' sebapoňatie študentky vo vzt'ahu $\mathrm{k}$ sebadiskrepačnej teórii? (3) Akým spôsobom uvažuje študentka o možnom vývoji svojho profesijného Ja? Dáta boli získané pomocou troch výskumných metód: vol'ného rozprávania, híbkového interview a zúčastneného pozorovania vyučovacej činnosti študentky. Dáta boli prepísané do transkriptov, ktoré boli podrobené otvorenému kódovaniu. $\mathrm{V}$ prvom kole bolo získaných 156 kódov, z ktorých boli potom vytvorené významové kategórie, napr. k prvej výskumnej otázke to boli kategórie obavy, uvedomované nároky na profesiu, osobné štandardy, odmietnutie. Výsledky sú prezentované v podobe vznikajúcej teórie, ktorá je rozsiahle dokumentovaná citátmi z transkriptov. Kredibilitu výskumu podporila možnost' kontrolovat' postup autorky (uvedený je podrobný opis činnosti) a bohatý dátový materiál vztahujúci sa k interpretačnému súhrnu.

Výskum Adamsa, Walkera a O'Connella (2011) a výskum Pravdovej (2012) sú založené na protichodnej metodologickej orientácii. Obidva však spájajú jednotlivé kroky opísané vyššie - existencia hypotéz, resp. výskumné otázky, ktoré smerujú $\mathrm{k}$ dátam, textová forma dát, kódovanie a interpretačné závery. Klúčové je pritom „natočenie“ výskumných otázok, resp. existencia hypotéz, z ktorých sa odvíjajú náplne ostatných komponentov výskumu - spôsob získavania dát a ich forma.

V tomto článku budeme hovorit’ len o obsahovej analýze v koncepcii, ako bola uvedená vyššie a jej jednotlivé prvky postupne opíšeme. $Z$ tohto podania je jasné, že aj ked' jadrom tejto výskumnej koncepcie je analýza obsahu textov, analýzou sa celý výskumný proces nezačína, ba ani nekončí. Pred analýzou je potrebné stanovit' výskumné otázky, vybrat' texty, určit' jednotku analýzy. Po ukončení analýzy je nevyhnutné dáta zhrnút' a interpretovat'. Nejde teda len o analýzu, ako názov napovedá, ale aj o iné procesy, a preto je tento názov, žial', nepresný. ${ }^{1}$ Je to síce vágne, ale vžité pomenovanie, a preto ho budeme používat' aj my, aj ked' si jeho obmedzenia plne uvedomujeme.

\footnotetext{
Podobný terminologický a vlastne aj koncepčný problém existuje aj pri iných výskumných koncepciách , ktoré majú v názve slovo analýza - pri konverzačnej analýze, fenomenologickej analýze a analýze diskurzu. Napríklad konverzačná analýza predstavuje viac ako rozbor interakcie, je to samostatný výskumný smer, ktorý má vlastnú filozofiu, koncepciu, terminológiu a výskumné postupy. Jej zakladatel'mi boli H. Sacks, E. Schegloff a G. Jeffersonová.
} 


\section{Obsahová analýza čoho?}

Názov obsahová analýza sa vel'mi často používa bez predmetu, ktorý sa k nej vztahuje. To si vyžaduje odpovedat' na otázku, čo je predmetom analýzy, o aké obsahy ide.

Obsah je to, čo sa komunikuje. Je to určitý významový celok, súbor informácií alebo znakov, ktorý je viac alebo menej štruktúrovaný. Vypovedá o určitej skutočnosti, jave alebo procese. V̌̌etko, čo komunikujeme, má svoj obsah, prináša správu. Ked’̌̌e obsah vždy plní komunikačnú funkciu, funguje ako komunikát.

Z hladiska formy môžeme komunikáty rozdelit' na tri základné skupiny, podl'a toho, či majú a) verbálnu, b) vizuálnu alebo c) dvojakú (verbálnu a vizuálnu) formu.

- Verbálnu formu majú napríklad časopisecké články, knihy, dizertácie, písomné práce žiakov, denníky učitelov, kurikulárne programy, kurikulárne dokumenty, legislatívne dokumenty, inšpekčné správy, e-mailové správy.

- Vizuálnu formu majú napríklad obrazy, fotografie, mapy, schémy, nákresy.

- Dvojakú formu majú napríklad portfóliá žiakov, učebnice, mapy, videá, webové stránky, televízne programy.

Komunikáty môžu byt' ad hoc materiály, to znamená texty, ktoré boli vytvorené pre konkrétny výskum na základe zadania výskumníka (napr. životopisné rozprávanie učitelov, ktoré výskumník nahral a potom obsahovo analyzoval), alebo sú to hotové materiály, ktoré vznikli mimo pôsobenia výskumníka, ten ich preberá a analyzuje. Sú to napríklad novinové články, učebnice, pracovné listy, kurikulárne dokumenty a pod.

Azda najfrekventovanejším komunikátom je text, teda viac alebo menej súvislý verbálny prejav. Ten bude hlavným predmetom nášho opisovania obsahovej analýzy. Vizuálnym komunikátom sa budeme venovat' len okrajovo.

Krippendorff (2004, s. 24) silne zdôrazňuje, že komunikáty nevznikli ani nefungujú vo vzduchoprázdne, ale v konkrétnom kontexte. Kontext je dôležitý, pretože pridáva komunikovanému obsahu další význam. Niekedy dokonca bez poznania kontextu nie je možné komunikát pochopit'. 
Ak sa pozrieme na preferencie nášho súboru autorov určených na rozbor, len Berelson (1952) a Holsti (1969) trvajú na mediálnom obsahu. Neuendorfová (2002), Krippendorff (2004), Berg (1995), Whiteová s Marshovou (2006) a Guest a kol. (2012) umožňujú analyzovat’ obsah s akýmkol'vek zameraním. Rozdiel medzi týmito dvomi skupinami odráža vývoj obsahovej analýzy. Berelson a Holsti patria medzi pionierov a pracovali v čase, ked' sa analyzoval pomerne úzky rozsah textov. Zvyšok autorov predstavuje súčasnú éru. Ich závery platia pre akýkolvvek obsah - verbálny, vizuálny alebo iný.

\section{$4 \quad$ Výber vzorky textov}

Klúčovým prvkom obsahovej analýzy, ktorý sa stanovuje hned' po konkretizácii výskumného ciela, je rozhodnutie o tom, ktoré texty budeme vyberat' a akým spôsobom. Pri obsahovej analýze stanovujeme tri rôzne jednotky. Je to výskumná vzorka, jednotka zberu dát a jednotka analýzy. Výskumná vzorka hovorí o tom, ktoré texty z populácie textov boli do výskumu vybraté. Kritérium zberu dát špecifikuje zameranie týchto textov. Jednotkou analýzy je konkrétny prvok, ktorý sa v textoch analyzuje a o ktorom výskumník podáva výskumné závery. Pri obsahovej analýze môže byt' jednotkou analýzy akýkol'vek textový element: slovo, slovné spojenie, odsek, téma.

Vo výskume Syslovej a Najvarovej (2012) boli stanovené dve výskumné otázky: (a) akými témami sa zaoberal český pedagogický výskum v oblasti predškolského vzdelávania a (b) aké konkrétne poznatky tento výskum priniesol. Populáciu textov tvorili empirické štúdie v časopisoch Československá psychologie, Komenský, Orbis Scholae, Pedagogická orientace, Pedagogika, Sociologický časopis a Studia paedagogica v rokoch 2000-2010. Kritériám plnohodnotnej empirickej štúdie vyhovelo 10 textov. Ďalej boli do výskumného súboru vybraté empirické štúdie zo zborníkov ČAPV a zo štyroch zborníkov z konferencií k tematike predškolského vzdelávania v ČR, tiež v období 2000-2010 (30 textov). Kritériom zberu dát boli výskumné štúdie $\mathrm{v}$ autorkami stanovených časopisoch a zborníkoch. Jednotkou analýzy boli tematické okruhy, ktoré boli predmetom týchto štúdií a poznatky, ktoré tieto štúdie priniesli.

Vztahah medzi výberom vzorky, výberom jednotky zberu dát a výberom jednotky analýzy je niekedy zložitý, pretože tieto prvky môžu splývat' (Neundorfer, 2002, s. 71).

Výber textov z populácie je vždy dôležitou otázkou pre výskum, pretože ovplyvňuje šírku záverov i možnosti interpretácie. Obsahová analýza musí 
pristupovat' $\mathrm{k}$ výberu vzorky systematicky. To znamená, že texty sa vyberajú na základe vopred určených charakteristík a výsledkom výberu je určitý systém textov (teda nie l'ubovol'né zoskupenie).

Pokial' ide o výber vzorky pre obsahovú analýzu, bud' ide o stochastický (náhodný) výber, alebo o nestochastický, presnejšie intencionálny výber. Tretia možnost' je dostupný (convenient) výber, ale ten nie je systematický a jeho použitie je vhodné skôr na pilotné štúdie než na plnokrvný výskum, pretože miera jeho reprezentatívnosti (pri kvantitatívnom výskume), resp. kredibility (pri kvalitatívnom výskume) je nízka. Dostupný výber sa riadi sloganom „beriem, čo môžem“. Nie je to však námatkový výber, pretože pri ňom funguje istá miera náhodnosti, i ked' nekontrolovaná.

Berelson (1952), Neuendorfová (2002) i Krippendorff (2004) počítajú len so stochastickým výberom, pretože iba ten podla nich zodpovedá štandardom dobrej vedy. Rozlišujú výber systematický, klastrový, stratifikovaný, viackolový (multistage) a kvótny. Ide o klasické typy stochastického výberu, bežne odporúčané pri kvantitatívnych výskumoch. Intencionálny výber je u týchto autorov skôr výnimkou; volí sa len v mimoriadnych a dobre zdôvodnených prípadoch.

Základné kroky pri stochastickom výbere sú jasne stanovené a v metodologickej literatúre sú dobre opísané. Krippendorff (2004, s. 113) však tvrdí, že pri obsahovej analýze sa ich aplikácia komplikuje. Výskum založený na analýze textových materiálov má tažkosti s určením populácie. Ten je potrebný pri stochastickom výbere vymedzit', ked'že všetky jednotky populácie musia mat' rovnakú šancu dostat' sa do výberu. Otázkou je, kde sú hranice danej populácie. Z výberového hl'adiska je každá jednotka populácie rovnocenná s inou jednotkou populácie. Pri niektorých materiáloch určených na obsahovú analýzu (e-mailoch, listoch, webových stránkach, televíznych programoch apod.) je niekedy populáciu t'ažké vymedzit'. Krippendorff to rieši rešpektovaním autority výskumných otázok. Výber sa uskutoční tak, aby výskumník získal na ne odpovede a aby tieto odpovede boli čestné (fair). Krippendorff píše aj o relevantnom výbere, ktorý sa približuje zámernému výberu. Výsledkom tohto výberu však nie je reprezentatívna sada textov z hladiska populácie. Je to „populácia relevantných textov, ale zbavená textových jednotiek, ktoré neobsahujú relevantné informácie" (Krippendorff, 2004, s. 119). 
Podla Guesta et al. (2012, s. 7-8) je intencionálny výber typický pri exploračných výskumoch, ktoré nie sú riadené vstupnou hypotézou. Konfirmačný výskum je, naopak, organizovaný tak, aby hypotézy, stanovené na začiatku výskumu, testoval, t.j. potvrdil alebo vyvrátil. Berg, ktorý je symbolický interakcionista, opisuje postupy zakotvenej teórie, ale jedným dychom hovorí o použití akéhokol'vek spôsobu výberu, teda intencionálneho i stochastického (Berg 1995, s. 178-181).

Výber vzorky pre kvalitatívne účely si vyžaduje dôkladný opis a zdôvodnenie spôsobu výberu. Je to dôležité pre to, aby procedúry vzbudzovali dôveryhodnost' vo výskumné postupy bádatel'a a sprostredkovane aj pre závery jeho výskumu.

Spôsob výberu vzorky textov ovplyvňuje jej vel'kost'. Intencionálny výber má malú vzorku, a tá súvisí s híbkou analýzy - je hlbšia a zaberá ovela viac času. Stochastický výber musí mat' vel'kú vzorku, aby výsledky dosiahli reprezentatívnost', a výskumník si preto zvyčajne nemôže dovolit' hlbšiu analýzu (o latentnom a manifestnom obsahu budeme hovorit' v časti 5).

V kvalitatívnom výskume existuje pravidlo, ktoré určuje vel'kost' vzorky - je to moment dosiahnutia teoretickej saturácie, teda nasýtenosti teórie dátami (Strauss \& Corbinová, 1999, s. 140). Presnejšie ide o nasýtenie jednotlivých významových kategórií a schopnost' vysvetlit’ vzt'ahy medzi nimi. Nastáva vtedy, ked' výskumník nadobudne pocit, že už žiadne nové relevantné významové kategórie sa v dalších textoch neobjavia a že to, čo doteraz vygeneroval, bude dobrým základom vznikajúcej teórie. V kvantitatívnom výskume je rozsah výskumnej vzorky diktovaný štatistickými zákonitostami. Podrobne o tom pojednáva Neuendorfová (2002, s. 88-93).

Aj ked' je v centre tejto štúdie je obsahová analýza textov, bude zaujímavé predstavit', ako sa s výberom vzorky vyrovnáva výskum, ktorý je založený na netextových prvkoch. Výber vzorky je pre takýto výskum často zložitejší. Ako príklad uvedieme televízne seriály.

Manganellová, Franziniová a Jordanová (2008) postupovali vo výskume sexuálneho správania mladých ludí v televíznych seriáloch takto. Z obdobia 1989-1999 vybrali desat' seriálov, ktoré sa podla prieskumu sledovanosti u mládeže vo veku od 12 do 17 rokov umiestnili na najvyšších priečkach, a to zhodne u dievčat i u chlapcov. Medzi vybranými seriálmi boli i tie, ktoré sú známe u nás, napr. Beverly Hills 90210, Priatelia alebo Simpsonovci. Jednotkou analýzy bola postava, ktorá zaujímala integrujúcu úlohu v deji. Postava ako jednotka analýzy bola 
zvolená preto, lebo pôvodným cielom výskumu bolo zistit’ vzt’ah medzi sexuálnym správaním postavy a jej osobným a profesijným úspechom. Kódovalo sa správanie postavy $\mathrm{v}$ každom diele, $\mathrm{v}$ ktorom sa postava objavila, a to $\mathrm{v}$ troch kategóriách (platonické, neplatonické alebo sexuálne správanie).

Ako vidno, išlo o zámerný výber vzorky (najsledovanejšie seriály), čo by sme očakávali u kvalitatívneho výskumu, ale spracovanie dát bolo kvantitatívne (zastúpenie typov sexuálneho správania v seriáloch). ${ }^{2}$

\section{Manifestný alebo latentný obsah}

Manifestný obsah je zjavný, je vyjadrený na povrchu komunikátu. Latentný obsah je skrytý, je akoby vložený medzi riadkami. Analogicky s lingvistikou môžeme povedat', že manifestný obsah textu predstavuje jeho povrchovú štruktúru, latentný jeho hĺbkovú štruktúru. Klasik obsahovej analýzy Berelson, podobne ako Holsti (1969, cit. podla Shapira a Markoffa, 2009), počítali len s manifestným obsahom. Ich stanoviská vyplývali z požiadavky, aby bol výskum objektívny, prísne kontrolovatel'ný. To si potom vyžaduje, aby sa analýza realizovala na manifestnej úrovni. Ako píše Krippendorff (2004, s. 20), tento prístup implikuje, že obsah je obsiahnutý v komunikáte a čaká, kým ho neobjavia a neanalyzujú. Na toto Krippendorff používa metaforu kontajnera. Obsah je vo vnútri kontajnera a nemožno pochybovat', že by sa nedal vnímat'. Analýza textu je v tejto koncepcii viac-menej technická záležitost' a významy vložené do textu autorom a významy získané výskumníkom z tohto textu sú vždy totožné. Miera nezávislej interpretácie výskumníkom je tu nízka. Pri výskume založenom na manifestnom obsahu sa obyčajne zistujujú frekvencie slov, slovných spojení, objektov, znakov.

Walshová a Pettyová (2007) uskutočnili obsahovú analýzu desiatich ročníkov časopisu Early Childhood Education (1995-2005), pri ktorom vyhladávali zastúpenie šiestich pedagogických koncepcií (niekde išlo len o programy): Waldorfská pedagogika, Montessoriovská pedagogika, Head Start, High/Scope, Reggio Emilia a Bank Street. Kritériom bol výskyt názvu týchto pedagogických koncepcií. V prípade, že sa v danom čísle časopisu vyskytol daný názov čo i len raz, bol zaznamenaný. Viacnásobný výskyt $\mathrm{v}$ jednom článku sa nezaznamenával. Výskumníčky nezaujímalo, ako autori článkov v tomto časopise interpretovali danú pedagogickú koncepciu, ani akým spôsobom ju uplatnili. Nezaujímalo ich ani či išlo o teoretický, výskumný alebo aplikačný článok. Výsledkom analýzy bol počet výskytov

2 Primárny ciel' tejto výskumnej štúdie bol metodologický - zistit’ najmenšie množstvo dielov seriálu, ktoré je dostatočné na reprezentatívny výskum. 
jednotlivých pedagogických koncepcií. Dodajme, že najväčšie zastúpenie mal program Head Start ${ }^{3}$, ktorý pokryl takmer polovicu zistení, na druhej strane Waldorfská pedagogika sa vyskytla len 1x, Montessoriovská 7-krát.

Ako je zrejmé, zistenia takéhoto výskumu sú vysoko reliabilné (t.j. zhoda pri kodéroch je takmer 100-percentná), ale nemajú vysokú poznávaciu hodnotu. To je typické pri mnohých analýzach manifestného obsahu textu. Ked’že poznávacia hodnota analýzy manifestného obsahu je nižšia, existuje len málo autorít obsahovej analýzy, ktorí ju vymedzujú výlučne na úrovni manifestného obsahu (Berelson, 1952; Holsti, 1969). Toto bolo skôr hladisko priekopníkov z prvej polovice minulého storočia, ktorí pracovali s materiálmi propagandy, napr. Lasswell (Neuendorf, 2002, s. 34-37).

Pri výskume založenom na latentnom obsahu musí výskumník prejst’ od povrchového významu $\mathrm{k}$ híbkovému. To, čo číta $\mathrm{v}$ transkripte a to, čo $\mathrm{z}$ neho extrahuje, je síce zviazané, ale nie doslovne. Ilustrujme to na ukážke.

Vo výskume adolescentov $\mathrm{v}$ detskom domove a vo výchovnom ústave pomocou fókusových skupín (Vávrová \& Gavora, 2015) respondenti diskutovali o svojich životných cieloch. Jeden z respondentov povedal:

P: Já jsem chtěl dělat vždycky číšníka, ne jako ... nakonec dělám s lopatou, tak asi skončím u lopaty, no. Nevím, ale mně se na jednu stranu chce dělat ten číšník, ale na druhou stranu ne, protože máma mi vždycky ř́kala - pokud se nebudeš učit, tak skončíš u lopaty, no, ale prostě já se učím, mám dobrý známky, ale stejně asi skončím u té lopaty, to je prostě...

Manifestný obsah vypovedá o práci s lopatou, želanom povolaní čašníka, o motivácii matkou učit' sa. Latentný obsah však vypovedá o neschopnosti respondenta vymanit' sa zo sociálneho prostredia, z ktorého pochádza.

Väčšina súčasných odborníkov zastáva pri vol'be analýzy manifestného/ latentného obsahu stanovisko postupovat' podla potreby a bud' zostat' len pri manifestnom obsahu, alebo prijat' aj latentný obsah (Neuendorf, 2002; Krippendorff, 2004). Kvalitatívni výskumníci analyzujú len latentný obsah (White \& Marsh, 2006; Guest et al., 2012). Guest a kol. sa o manifestnom obsahu vo svojej knihe ani nezmieňujú.

3 Head Start je americký program zameraný na podporu deti zo znevýhodneného sociálneho prostredia. Je financovaný z federálneho rozpočtu. 
Pri analýze latentného obsahu však výskumník musí začat’ na manifestnej úrovni, z ktorej sa dostane $\mathrm{k}$ latentnej úrovni textu. $\mathrm{Z}$ povrchovej roviny sa dostáva k „skrytej, neviditel'nej“ rovine. Doplňme, že v priebehu analýzy sa pohybuje od manifestného k latentnému obsahu a naopak.

Dvaja alebo viacerí výskumníci nemusia chápat’ komunikovaný obsah rovnako a výsledky ich analýz nemusia byt' celkom zhodné. Každá analýza latentného obsahu je originálnym interpretačným činom. V manifestnej interpretácii je obsah nádobou naplnenou istým významom. Autor textu a výskumník majú rovnakú nádobu a rovnaký obsah. V latentnej interpretácii je to iné, každý obsah je unikátny, špecifický a vyžaduje si subjektívnu interpretáciu výskumníkom. Niektorí bádatelia akceptujú prioritu analýzy latentného obsahu, ale vyžadujú nezávislú kontrolu jej interpretácie. Napr. Berg (1995) ponúka overenie interpretácie nezávislým posudzovatel'om - čo je povinný postup pri kvantitatívnej obsahovej analýze. Pri liberálnejšej verzii je potrebné doložit’ interpretáciu kódu dátovým materiálom, „pri každej interpretácii aspoň tromi samostatnými ukážkami“ (Berg, 1995, s. 176). Prirodzene, výsledok analýzy latentného obsahu možno triangulovat' použitím inej metódy alebo iného obsahu, čo je známa stratégia kvalitatívneho výskumu.

\section{Smer analýzy}

Rozhodujúcim prvkom výskumu je cesta od textov k výsledkom. Smer postupu považujú mnohé metodologické príručky za primárne rozlišovacie znamienko výskumného prúdu, koncepcie či dizajnu. Preto ho výskumníci často uvádzajú hned' na začiatku charakteristiky výskumu. Analýza sa môže pohybovat' od textového materiálu k záverom (teórii) alebo naopak, od teórie k dátam. V prvom prípade ju označujeme ako induktívny postup, $\mathrm{v}$ druhom ako deduktívny postup. $\mathrm{V}$ prvom prípade sa závery extrahujú $\mathrm{z}$ dát, $\mathrm{v}$ druhom sa dáta vztahujú k teoreticky vyčleneným kategóriám. Vol'ba smeru postupu závisí od rozhodnutia výskumníka, pričom súvisí i s dalǎšími komponentmi výskumu (výskumná otázka, resp. hypotéza, potvrdenie reliability, resp. dôkaz o kredibilite, výber a rozsah vzorky, zameranost' na latentný alebo manifestný obsah textu).

Radikalisti, ako je Neuendorfová akceptujú výlučne deduktívny postup. Induktívny postup pri obsahovej analýze považujú za nevhodný. Zdôvodnenie je nekompromisné: „Úplne induktívny prístup porušuje pravidlá vedeckého snaženia. Všetky rozhodnutia o premenných, spôsobe ich merania 
a pravidlách kódovania sa musia uskutočnit' pred začatím pozorovania." (Neuendorf, 2002, s. 11) Tieto pravidlá a kódy sa overia pred začatím analýzy, predovšetkým sa stanoví, aká je reliabilita kódovania.

Pri deduktívnej obsahovej analýze má výskumník pred začatím analýzy $\mathrm{k}$ dispozícii zoznam kódov, pravidlá ich používania (oboje v kódovej knižke) a kódovací hárok, do ktorého uskutočňuje záznamy. Kódy vznikli na základe štúdia teoretickej literatúry, výskumníkovej znalosti problematiky a diskusií s odborníkmi. Analýza prebieha ako vkladanie obsahových jednotiek do a priori pripravených významových kategórií. Pre Krippendorffa (2004, s. 82, 91) je výskum predovšetkým testovaním hypotéz, čo implikuje deduktívny postup. Ten zdôvodňuje aj potrebou replikácie výskumu. Každý výskum má byt' opísaný tak podrobne, aby sa dal presne zopakovat'. Týmto spôsobom sa výsledky opakovane potvrdia, čím sa stávajú pevnými, dobre overenými. Ak sa nepotvrdia, hladá sa zdroj odchýlky vo vstupnej teórii, vo vzorke, nízkej reliabilite a validite postupu alebo v chybách vo výpočtoch.

Celkove môžeme vyjadrit' typický deduktívny postup pri obsahovej analýze (s prihliadnutím na práce Poppinga, 2000; Krippendorffa, 2004 a Neuendorfovej, 2002, 2011) takto:

1. stanovenie východiskového teoretického rámca;

2. stanovenie výskumnej hypotézy;

3. stanovenie jednotky analýzy;

4. konceptualizácia obsahových kategórií (premenných) a ich definovanie;

5. operacionalizácia obsahových kategórií;

6. vytvorenie prvotnej kódovej schémy (zoznam kódov a ich opis);

7. vymedzenie vzorky textov;

8. výcvik kodérov;

9. predbežné overenie reliability, prípadné úpravy kódovej schémy;

10. výpočet finálnej reliability;

11. kódovanie;

12. spracovanie dát, tabul'kovanie výsledkov;

13. interpretácia dát vo vzt’ahu k východiskovej teórii. 
Induktívny postup je postup od textu ku kódom a od kódov k teórii. Kódy, ktoré vznikajú v priebehu analýzy, sú originálnym dielom výskumníka a sú neprenosné. Sú produktom subjektívnej interpretácie textu a dôveryhodnost' tejto interpretácie sa overuje posúdením postupu výskumníka, ktorý vo svojej výskumnej správe podrobne opísal. To je približne stanovisko Whiteovej a Marshovej (2006) a Guesta a kol. (2012, s. 7, 40). Je to pozícia výskumu $\mathrm{s}$ exploračnou orientáciou, ktorého sila je $\mathrm{v}$ otvorenom prístupe $\mathrm{k}$ budovaniu teórie. Berg (1995, s. 184-195) síce proklamuje pri obsahovej analýze začat' bud' induktívnym, alebo deduktívnym spôsobom podl'a potreby výskumníka, ale zoširoka opisuje len tvorbu zakotvenej teórie, ktorá sa však začína indukciou (cituje Glasera a Straussa, 1967; Denzina, 1978).

Aj ked' sú jednotlivé kroky pri induktívnom postupe štandardné, presnejšie povedané typické, výsledky, ktoré tento postup prináša, sú jedinečné, neopakovatel'né. Preto výsledky dvoch induktívnych postupov na tom istom textovom materiáli nemôžu byt' v podstate rovnaké a uplatňovanie kontroly zhody kódovania medzi kodérmi (určenie reliability) v tomto metodologickom rámci nemá význam - na rozdiel od deduktívnych postupov. K tejto problematike sa ešte vrátime.

Lenže situácia s induktívnym postupom je zložitejšia. Ked' výskumník vytvorí prvé kódy, v d’alších úsekoch textu ich použije pri kódovaní. Toto už nie je presne induktívny postup. Existujúce kódy nachádzajú uplatnenie v nasledujúcej sekvencii postupu. Preto treba byt' jemnejší pri chápaní induktívnosti v kvalitatívnom výskume. Výskumník pracuje v opakujúcich sa cykloch: niekol'kokrát sa vracia k údajom a opakovane overuje vhodnost' kódov. Niektoré kódy môže vyradit', iné modifikovat', d'alšie vytvorit' a tie použit' v d'alšej sekvencii kódovania. To je už deduktívny postup. Strauss a Corbinová (1999, s. 110) podporujú cyklický pohyb od dát k predbežným záverom (hypotézam) a spät' a hl'adanie dôkazov potvrdzujúcich, vyvracajúcich alebo upravujúcich tieto závery.

Analogicky môžeme opis situácie spresnit' i pri dominantne deduktívnom postupe. I ked' výskumník spravidla určí kódy apriórne, t.j. na základe teórie, často ich skontroluje na základe prvotnej analýzy dát na obmedzenom texte, pričom na jej základe kódy upraví, vypustí alebo vytvorí nové. Postupuje teda induktívne. Až potom nastúpi deduktívna čast' na celom korpuse textov. Induktívny a deduktívny smer analýzy budeme $\mathrm{v}$ tejto štúdii chápat’ $\mathrm{v}$ tom zmysle, ktorý postup je v danom výskume dominantný. 
Výskum založený na induktívnom postupe vyzerá takto (podla White \& Marsh, 2006; Forman \& Damschroder, 2008; Schreier, 2012):

1. stanovenie východiskového metodologického prístupu, vysvetlenie vedúceho hladiska, z ktorého sa bude nazerat' na obsah, ktorý sa má analyzovat;;

2. stanovenie predbežných výskumných otázok (foreshadowed questions);

3. stanovenie jednotky analýzy;

4. stanovenie vzorky textov;

5. analýza dát: vytváranie obsahových kategórií induktívnym spôsobom, ich definovanie (konceptualizácia), exemplifikácia a spätné overenie; tento postup sa opakuje, kým sa nedosiahne najlepšie riešenie, t.j. kým sa neodstránia nejednoznačnosti, protirečenia, prekrývanie kategórií apod.;

6. zoskupovanie a usporiadanie kategórií podla zmyslu; podla potreby sa kategórie organizujú do niekol'kých rovín s odstupňovanou úrovňou abstraktnosti;

7. reflexivita a kritická previerka predchádzajúceho postupu výskumníkom;

8. napísanie deskriptívneho a interpretačného súhrnu, vrátane použitia autentických citátov $\mathrm{z}$ analyzovaného materiálu, pritom sa využívajú rôzne modely, matice a schémy.

Deduktívny a induktívny postup tvoria dve protikladné smerovania analýzy textu, ale - ako sme spresnili - ich „čisté“ formy sú obmedzujúce. Preto výskumníci často podporia svoju prácu odklonom k opačnému postupu, čo je funkčné.

\section{Reliabilné verzus kredibilné}

Ked' dvaja l’udia kódujú text, obyčajne nedospejú k rovnakým výsledkom. Nielenže ich kódy môžu byt' odlišné, ale líšit' sa môžu už miestom umiestnenia kódu v texte (kódujú odlišné miesta). Prečo dochádza k týmto rozdielom? Text je zložitý komplex významov, ktoré môže každý človek odhal'ovat' vlastným, svojbytným spôsobom. To sa prejaví už pri prvom kroku kódovania stanovením vel'kosti segmentov textu určeného na kódovanie. Niekto kóduje väčšie celky, iný menšie. $Z$ toho potom vyplynie aj nerovnaký počet kódov $\mathrm{v}$ danom texte, čiže ich hustota. Iný rozdiel môže vyplynút' z nerovnakej 
interpretácie toho istého segmentu textu, čo potom vedie k rôznym kódom. Ďalším dôvodom môže byt' odlišné chápanie samotných kódov. Kód, ktorý bol dohodnutý a vysvetlený, kodéri pochopili odlišne. Všetky štyri zdroje odlišností - vel'kost' segmentu, hustota kódovania, interpretácia segmentu a interpretácia kódu - vedú k odlišnému kódovaniu a teda k odlišným záverom analýzy. ${ }^{4}$

Výskumník má dve možnosti. Prvou je zodpovedný výber kodérov a ich dôkladný výcvik s cielom dosiahnut' čo najväčšiu zhodu. ${ }^{5} \mathrm{Na}$ výpočet reliability, teda zhody medzi kódovaním dvoch alebo viacerých kodérov sa používajú štatistické metódy. Neuendorfová (2002) uvádza osem metód - niektoré sú vlastne štandardnými koeficientmi korelácie, ktoré sú známe z korelačných výskumov (koeficienty Spearmana a Pearsona), iné sú špecifické pre výpočet reliability pri obsahovej analýze (Krippendorffova alfa, Scottov pí, Cohenova kappa).

Berelson (1952), Holsti (1969), Krippendorff (2004) a Neuendorfová (2002) považujú dostatočnú reliabilitu za základný predpoklad dobrej obsahovej analýzy. Reliabilita súvisí s validitou. Síce ju nevie zabezpečit', ale je jej nevyhnutnou podmienkou.

Druhou možnost'ou je postavit' výskum na kredibilite, transferabilite, dependabilite a konfirmabilite, o čom výskumník podáva podrobnú správu (Lincolnová \& Guba, 1985). ${ }^{6}$ Toto je prístup, ktorý rezignuje na objektivitu a reliabilitu a hl'adá hlbšie súvislosti a hlavne novšie alebo tvorivejšie výskumné riešenia.

Richards (2009, s. 108) zdôrazňuje skôr potrebu konzistencie kódovania u jedného výskumníka než o skúmanie intersubjektovej zhody. Ked' výskumník už vygeneroval svoj systém kódov, musí ho používat' verne a dôsledne

4 Ďalším zdrojom rozdielov môže byt' odlišné chápanie výskumnej otázky, ktorá riadi celý výskumný proces, prípadne dokonca iný teoretický rámec výskumníkov alebo ich odlišné epistemologické východiská.

5 Kripppendorff (2004) venoval výberu a výcviku kodérov samostatné podkapitoly svojej knihy.

6 Kredibilita je vlastnost' výskumu vzbudit’ dôveru. Zabezpečuje sa dôkladným poznaním skúmaného terénu výskumníkom, trianguláciou, skúmaním protikladných prípadov a spätnou verifikáciou zistení (member check). Transferabilita sa zabezpečuje tzv. masívnym opisom, dependabilita externým auditom a konfirmabilita pomocou zápisu zrodu interpretácie (audit trail) a reflexivitou. Pre celý tento súbor postupov budeme pre stručnost' používat' výraz kredibilita. 
v celej d'alšej časti výskumu. To býva problémom najmä vtedy, ked' ide o dlhý výskum, alebo ked' je predmetom výskumu vela textov.

Švaříček so Šed'ovou (2007) podali správu o tom, k akým výsledkom vedie práca dvoch výskumníkov kódujúcich totožný text otvoreným kódovaním, typickým pre kvalitatívny výskum. Obidvaja kódovali text samostatne a vytvorili vlastné kódy. Zhodli sa síce prekvapujúco v počte vytvorených kódov (čo mohla byt' náhoda), ale totožné boli len tri kódy. Autori podrobne opisujú, $\mathrm{z}$ čoho pramenili rôzne postupy, ktoré viedli k rôznym výsledkom. Hlavným rozdielom bol odlišný základný uhol pohladu, ktorým nazerali na analyzovaný text (išlo o naratívne interview). Autori ukázali, že separátne kódovanie vedie skôr k objaveniu nových aspektov a nových tém než k potvrdeniu zhody. To nie je nedostatok, ale výhoda kvalitatívneho výskumu.

Ani Altheide (1987) ani Whiteová s Marshovou (2009) nepočítajú vo výskume so zist'ovaním reliability. Berg (1995) požaduje kredibilitu, ale povoluje aj reliabilitu, podobne ako Guest a kol. (2012, s. 85). V prípade týchto výskumníkov išlo o kolektívny výskum, čo si, samozrejme, vyžaduje iný projekt výskumu a kontrolu kodérov, ktorí v ňom pôsobia, aby boli výsledky konzistentné. Vo vel'kých výskumoch je časté zamestnávat' profesionálnych kodérov, ktorí však nechodia do terénu a participantov ani nevidia. Zážitok autenticity z terénu bol však jedným z najsilnejších faktorov, ktoré ovplyvnili individuálne hl'adiská kódovania, o ktorom referovali Švaříček so Šed'ovou (2007).

Z publikovaných zahraničných výskumov využívajúcich kvalitatívnu obsahovú analýzu vyplynula istá tendencia priklonit’ sa k „ošetreniu“ analýzy formou kredibility vtedy, ked' boli predmetom analýzy texty vytvorené ad hoc, teda pre konkrétny výskum. Tak to býva v prípade tematického písania, narácie alebo transkriptov interview vrátane interview fókusových skupín. Na druhej strane sa prejavila istá tendencia, že pri analýze hotových textov, t.j. textov, ktoré nevznikli pre konkrétny výskum, sa napriek celému kvalitatívnemu ladeniu kontroluje kódovanie pomocou zistenia zhody nezávislých kodérov. Tak je to v prípade textov médií, školských dokumentov, zápisníc z porád a pod. Dobrým príkladom je nasledujúci výskum.

M. Brownová (2013) zistovala, ako je problémové správanie subjektov zakotvené $\mathrm{v}$ študijných programoch výchovného poradenstva na amerických univerzitách. Táto problematika je dôležitá kvôli zabráneniu vstupu študentov s touto charakteristikou do štúdia, resp. pre nápravu tohto správania počas štúdia 
alebo po jeho ukončení. Problémové správanie výchovného poradcu je profesionálne nevhodné, škodiace riadnemu vykonávaniu profesie. Autorka analyzovala 47 študijných programov, ktoré boli dostupné z webových stránok univerzít. Cielom bolo zistit', ako tieto programy definujú a diagnostikujú problémové správanie študentov, resp. umožňujú jeho nápravu. Jednotkou analýzy bola téma problémového správania. Autorka nakódovala najprv text jedného študijného programu otvoreným kódovaním a vytvorila tak zoznam kódov. Ten potom dvaja výskumníci overili samostatným kódovaním. Zist’ovala sa teda reliabilita.

\section{Forma vyjadrenia výsledku výskumu}

Tento komponent obsahovej analýzy ukazuje, v akej podobe sa prezentujú výsledky výskumu. Možnosti sú tri - numerická, verbálna alebo oboje. Prirodzene, vol'ba podoby prezentácie výsledkov výskumu nie je izolovaným prvkom obsahovej analýzy, ale súvisí s jej d’alšími komponentmi - formuláciou výskumnej otázky, výberom a rozsahom vzorky, spôsobom kontroly kvality analýzy atd'.

Numerická podoba výsledkov výskumu vzniká spracovaním dát pomocou štatistických metód. Autor „redukuje“ vel'ké množstvo dát do tabuliek a grafov. Predmetom kvantifikácie sú slová, slovné spojenia a témy. Obvyklými výstupmi sú súčty a frekvencie. Novším spôsobom je určenie intenzity pojmu - je to vlastne jeho valencia stanovená výskumníkom v podobe škály. Vzt'ahové dáta sa vyjadrujú pomocou koeficientov asociácie a korelácie. Používajú sa aj zložitejšie metódy, ako je regresná analýza, faktorová analýza, multidimenziálne škálovanie a klastrová analýza (o štatistických metódach v obsahovej analýze píše napr. Roberts, 2009). Numerický prístup sa však uplatňuje nielen pri vyjadrení výsledkov výskumu, ale aj pri stanovení výskumnej vzorky - tú možno exaktne vyberat' na základe kvantitatívnych parametrov. ${ }^{7}$

Verbálna podoba výsledkov výskumu. Kým predchádzajúci spôsob analýzy sa začína slovami a vetami a končí sa pri číslach, tabul'kách a grafoch, kvalitatívna analýza zostáva tam, kde začala - pri slovách. Ale aj v jej prípade ide o „redukciu“ pôvodného textu, presnejšie o jeho kondenzáciu. Konkrétna podoba výsledkov záleží na koncepcii výskumu a preferenciách autora. Návody

Prehlad o existujúcich softvéroch pre kvantitatítvnu analýzu obsahu možno nájst’ v práci Neuendorfovej (2002) a Poppinga (2000). Druhý autor zahrnul do prehladu aj softvéry na kvalitatívnu analýzu obsahu. Čerstvejšie informácie prinášajú Guest a kol. (2012). 
na prezentáciu výsledkov výskumu poskytujú Strauss a Corbinová (1999), Novotný (2007), Guest a kol. (2012) a Šedová so Švaříčkom (2013).

Obyčajne sa opis začína uvedením hlavných významových kategórií, centrálnych pojmov, alebo najvýznamnejších tém. Tieto kategórie sa vztahujú k teoretickému rámcu, ktorý bol vysvetlený na začiatku výskumu a samozrejme k výskumným otázkam. Výklad pokračuje predstavením d'alších kategórií a celkový konceptuálny systém je obyčajne znázornený vo forme grafu alebo tabul'ky. Výklad je podporený dátovým materiálom, ktorý výstižne ilustruje (ale nenahradzuje) teoretický koncept. Zistenia sa dávajú do vzt’ahu s inými výskumami.

Pokial' ide o preferenciu spôsobu prezentácie výsledkov, skúmaní autori sa delia na tri skupiny. Berelson, Holsti, Neuendorfová a Krippendorff zhodne preferujú numerickú formu. Whiteová a Marshová uprednostňujú verbálnu formu. Berg a Guest a kol. prijímajú obidve formy.

\section{Celkový pohlad na súčasné podoby obsahovej analýzy}

Doteraz sme predstavili súčasné podoby obsahovej analýzy tak, že sme ukázali jej konštitučné komponenty, ich náplne a súvislosti medzi nimi v rôznych existujúcich variantoch. Týchto komponentov bolo šest’ a každá mohla mat' dva až tri druhy náplní:

1. typ analyzovaného obsahu: mediálny alebo bez obmedzenia;

2. výskumná vzorka: stochastická a/alebo intencionálna;

3. hĺbka analýzy: manifestná a/alebo latentná;

4. smer postupu: deduktívny a/alebo induktívny;

5. druh kontroly analýzy dát: intersubjektová zhoda a/alebo kredibilita;

6. forma vyjadrenia výsledku výskumu: numericky a/alebo verbálny.

V tejto časti súhrne ukážeme, aké varianty komponentov a ich náplní tento systém preukázal. Ako je zjavné z literatúry, ktorú sme použili, sme vybrali také práce, ktoré nám umožnili ukázat' čo najčlenitejší pohl'ad na postupy obsahovej analýzy, presnejšie na existenciu rôznych konfigurácií jej konštitučných komponentov a ich náplní. Výber nezohladňuje frekvenciu rôznych variantov obsahovej analýzy v existujúcich výskumoch; náš prístup bol skôr 
typologický ako štatistický. Zistenia sme koncentrovali do tabul'ky 1, ktorá znázorňuje autorov, jednotlivé konštitučné komponenty obsahovej analýzy a alternatívy ich náplní.

Tabul'ka 1 ukazuje, že existujú krajné varianty obsahovej analýzy s náplňami komponentov orientovaných protikladne (Berelson a Holsti verzus Whiteová a Marshová). Predstavujú to, čo sa v tradičnej terminológii vyjadruje na jednej strane ako kvantitatívny a na druhej strane ako kvalitatívny prístup (prúd, paradigma, metodológia). Varianty obsahovej analýzy, ktoré ležia medzi týmito krajnými polohami, a ktoré reprezentujú štyri zo siedmich prác v našom výbere, ukazujú rozsah možností. Len v jednom komponente (typ obsahu) sú zhodné, v ostatných sú rozdielne. V tradičnej terminológii sa tieto varianty nazývajú zmiešaný metodologický prístup.

Tabul'ka 1

Náplne konštitučných komponentov obsahovej analýzy u rôznych autorov

\begin{tabular}{|c|c|c|c|c|c|}
\hline Autori & $\begin{array}{c}\text { Berelson } \\
\text { (1952); Holsti } \\
\text { (1969) }\end{array}$ & $\begin{array}{c}\text { Neuendorf } \\
\text { (2002); } \\
\text { Krippendorff } \\
(2004) \\
\end{array}$ & Berg (1995) & $\begin{array}{c}\text { Guest } \\
\text { et al. (2012) }\end{array}$ & $\begin{array}{c}\text { White a Marsh } \\
\text { (2006) }\end{array}$ \\
\hline $\begin{array}{l}\text { Typ } \\
\text { obsahu }\end{array}$ & mediálny & \multicolumn{4}{|c|}{ bez obmedzenia } \\
\hline $\begin{array}{l}\text { Výber } \\
\text { vzorky }\end{array}$ & \multicolumn{2}{|c|}{ stochastický } & $\begin{array}{l}\text { stochastický } \\
\text { i intencionálny }\end{array}$ & \multicolumn{2}{|c|}{ intencionálny } \\
\hline $\begin{array}{l}\text { Híbka } \\
\text { analýzy }\end{array}$ & manifestná & \multicolumn{2}{|c|}{ manifestná i latentná } & \multicolumn{2}{|c|}{ latentná } \\
\hline $\begin{array}{l}\text { Smer } \\
\text { postupu }\end{array}$ & \multicolumn{2}{|c|}{ deduktívny } & $\begin{array}{l}\text { induktívny } \\
\text { i deduktívny }\end{array}$ & \multicolumn{2}{|c|}{ induktívny } \\
\hline $\begin{array}{l}\text { Druh } \\
\text { kontroly } \\
\text { dát }\end{array}$ & \multicolumn{2}{|c|}{ intersubjektová zhoda } & \multicolumn{2}{|c|}{$\begin{array}{l}\text { intersubjektová zhoda } \\
\text { a kredibilita }\end{array}$} & kredibilita \\
\hline $\begin{array}{l}\text { Forma } \\
\text { výsledkov } \\
\text { výskumu }\end{array}$ & \multicolumn{2}{|c|}{ numerický } & \multicolumn{2}{|c|}{ verbálny i numerický } & verbálny \\
\hline
\end{tabular}


Z nášho uhla pohl'adu sa však na pomenovanie zmiešaný prístup nezdá vhodné. Posúva totiž problematiku výskumu do nežiaducich konotácií a skresl'uje prácu výskumníka. V skutočnosti nejde o miešanie nejakých entít výskumu. Výskumník nemieša, ale skôr stavia, konštruuje. Preto sme v našom prehlade variantov obsahovej analýzy použili výraz konštitučný komponent. Výskumník má k dispozícii komponenty, vyberá pre ne náplne a postaví z nich výskumný projekt, ktorý realizuje. Tento postup zodpovedá metafore stavby.

Vrát'me sa k tabul'ke 1. Zameranie Berelsona (1952) a Holstiho (1969) na texty médií vyplynulo z vtedajšej objednávky doby a preferencií skúmat' hlavne takéto texty. Ostatní autori nemajú nijaké obmedzenia pokial' ide o typ obsahu, ktorý má byt' predmetom obsahovej analýzy (aj ked' ich vlastné výskumy sa sústred'ujú len na jednu, príp. niekol'ko typov obsahu). Tento konštitučný komponent azda najmarkantnejšie odráža posuny, ktoré vznikli v priebehu času v doméne obsahových analýz. Dnes sú predmetom obsahovej analýzy aj texty prenášané elektronicky, webové stránky, filmy a televízne programy atd'.

Pokial' ide o výber výskumnej vzorky, boli zistené tri možnosti. Okrem výlučne stochastického a výlučne intencionálneho výberu sa v jednom prípade (Berg, 1995) objavili obidve alternatívy. Toto je zvláštne riešenie, ktoré sa zdá byt' nelogické, ale len dovtedy, kým si nevšimneme, že v d'alšom komponente, v híbke analýzy, Berg umožňuje tiež dve možnosti. To predpokladá spojenie stochastickej vzorky s deduktívnym postupom a intencionálnej vzorky s induktívnym postupom. Teoreticky je síce možné vybrat' výskumnú vzorku stochasticky a pracovat' induktívne a vice versa, ale nie je to zmysluplné.

Pri hĺbke analýzy sa ukázali tiež tri možnosti: manifestná, latentná a obidve alternatívy súčasne. Výlučne manifestný obsah a výlučne latentný obsah diferencujú dva úplne odlišné prístupy v obsahovej analýze. Podobne ako pri type obsahu a výskumnej vzorky, aj v tomto prípade diferencuje dve krajné podoby obsahovej analýzy. Berelson (1952) a Holsti (1969) verzus Guest a kol. (2012) a Whiteová s Marshovou (2006). Berg (1995) je verný svojej koncepcii obsahovej analýzy aj v tomto komponente - ponúka obidve alternatívny. Neuendorfová (2002) a Krippendorff (2004) týmto trošku zmäkčujú svoju inakšie dost' pozitivistickú koncepciu obsahovej analýzy.

Smer postupu je zásadným komponentom v koncepcii obsahovej analýzy. Apriórne stanovené kódy $\mathrm{v}$ prípade deduktívneho postupu a $\mathrm{z}$ dát extrahované kódy v prípade induktívneho postupu tvoria pomyselnú hranicu medzi 
dvomi svetmi obsahovej analýzy. Ide o postupy zhora dolu verzus zdola hore, postup od teoreticky vyvodených kategórií a ich naplňovanie dátami verzus postup od hladania kategórií $\mathrm{v}$ dátach a budovania teórie na ich základe. Berelson, Holsti, Neuendorfová a Krippendorff sú predstavitelia deduktívneho postupu, Guest a kol. a Whiteová s Marshovou reprezentujú induktívny postup. Berg je verný svojej univerzalistickej koncepcii. Umožňuje induktívny i deduktívny postup.

Druh kontroly dát súvisí s preferovaním bud' intersubjektovej zhody (overenie reliability kódovania), alebo akceptovaním subjektivity výskumníka (kredibilita, transferabilita, dependabilita, konfirmabilita). U Guesta a kol. tento komponent vybočuje $\mathrm{z}$ línie náplne ich predchádzajúcich štyroch komponentov a ponúkajú obidve alternatívy. Toto je však vysvetlitel'né orientáciou autorov na tímový výskum. Pri kódovaní vel'kého objemu textov viacerými kodérmi potrebovali zabezpečit' jednotu chápania kódov v teame. ${ }^{8}$ Skúsenosti z vlastného výskumu Guest et al. povýšili na princíp. Pripúštajú však i alternatívu kredibility.

Posledný komponent, forma vyjadrenia výsledku výskumu, kopíruje rozloženie autorov pri predchádzajúcom komponente. Numerické dáta zodpovedajú výskumu, ktorý smeruje k zovšeobecneniu na danú populáciu textov, zatial' čo verbálne vyjadrenia výsledkov zosobňujú perspektívy subjektov (autorov textu a výskumníka). Berg a Guest a kol. opät' ponúkajú obidve možnosti, čo je v súlade s druhmi kontroly analýzy, ktoré si zvolili. Ostatní predstavujú jednu možnost', v jednej alebo druhej forme.

Celkový pohlad na tabul'ku 1 umožňuje vyslovit' tento záver. Ak rešpektujeme navrhnutú metaforu, že projekt výskumu je stavbou, ktorú výskumník buduje, potom má výskumník možnost' vol’by náplne komponentov výskumu z dvoch až troch alternatív. Jeho vol'ba je však čiastočne obmedzená. Náplne totiž nemožno volit' l'ubovol'ne, ale len $v$ určitých konfiguráciách, pričom počet možností je konečný a je uvedený v tabul'ke 1. Nemožno mat' napríklad intencionálny výber, deduktívny smer analýzy a verbálne vyjadrenie výsledku (resp. to nie je metodologicky zmysluplné), alebo mat' stochastický výber, induktívny smer analýzy a numerické výsledky.

8 Podobne je motivovaná snaha Morettiovej a kol. (2011).V tomto prípade išlo nielen o tímový, ale dokonca o medzinárodný výskum. 
Z hladiska chronologického vidíme v tabul'ke 1 posun od „tvrdej“ koncepcie, ako ju reprezentujú najstaršie práce (Berelson a Holsti) smerom k novším prácam k Neuendorfovej a Krippendorffa (ten je v oproti prvému vydaniu svojej knihy v roku 1980 mäkší), d’alej smerom k Bergovi a Guestovi a kol. Druhým pólom je koncepcia Whiteovej a Marshovej. Tá dobre reprezentuje „mäkkú" podobu obsahovej analýzy.

\section{Záver}

Táto štúdia bola založená na dvoch východiskových momentoch: (1) Obsahová analýza prešla od svojho vzniku v pät'desiatych rokov minulého storočia značným žánrovým a tematickým obohatením (nové textové žánre, elektronické texty, texty pochádzajúce z kvalitatívnych výskumných štúdií interview, narácie, neštruktúrované pozorovanie). (2) Obsahovú analýzu ovplyvnili zásady a postupy kvalitatívneho výskumu (nové výskumné otázky, subjektivita výskumníka atd'.) Ako vidno, išlo o žánrové, tematické i o metodologické obohatenie.

Obidva tieto momenty mali dopad na všetky zásadné komponenty obsahovej analýzy. V štúdii sme sa pokúsili urobit' systematický prehl'ad možností súčasnej obsahovej analýzy, a to v podobe jej rozkladu na konštitučné komponenty. Opísali sme, aké ich konfigurácie existujú, aké sú ich náplne a vztahy medzi nimi. Výsledok nás potešil, pretože sme našli pomerne široký rozsah možností a zaujímavé riešenia, ktoré umožňujú urobit' z obsahovej analýzy flexibilnú základňu výskumu.

Obmedzenia tejto štúdie sú zjavné. Za základ analýzy slúžili metodologické knihy, nie výskumné štúdie. Náš prístup sme zdôvodnili tým, že v tejto etape práce nás zaujímala skôr typológia možností než ich frekvencia $\mathrm{v}$ empirickej praxi. Táto typológia však môže slúžit' ako dobré východisko pre d'alšie skúmanie obsahovej analýzy, okrem iného založeného na jej podobách v empirických výskumných štúdiách. Priznávame sa, že spôsob, ktorý sme pri analýze zvolili, mal aj určité didaktické motívy. Pri vyučovaní metodológie výskumu sa ním dobre vysvetl'ujú a ilustrujú metodologické možnosti. Presnejšie, tento prístup ukazuje, že polarizovanie obsahovej analýzy na kvantitatívnu a kvalitatívnu je zjednodušené a že je lepšie skôr rozoberat' jej komponenty a pochopit' vztahy medzi nimi. 


\section{Literatúra}

Adams, M., Walker, C., \& O'Connell, P. (2011). Invisible or involved fathers? A content analysis of representations of parenting in young children's picturebooks in the UK. Sex Roles, 65(3-4), 259-270.

Altheide, D. (1987). Ethnographic content analysis. Qualitative Sociology, 10(1), 65-77.

Berelson, B. (1952). Content analysis in communication research. New York: Free Press.

Berelson, B., \& Lazarsfeld, P. F. (1948). The analysis of communication content. Chicago: University of Chicago Press.

Berg, B. L. (1995). Qualitative research methods for the social sciences. Boston: Allyn and Bacon.

Brown, M. (2013). A content analysis of problematic behaviour in counselor education programs. Counselor Education and Supervision, 52(3), 179-192.

Denzin, N. K. (1978). The research act: A theoretical introduction to sociological methods. New York: McGraw-Hill.

Devi, N. B. (2009, May). Understanding the qualitative and quantatitive methods in the context of content analysis. In Qualitative and Quantitative Methods in Libraries, International Conference organised by International Federation of Library Associations (s. 26-29).

Dvořáková, H. (2010). Obsahová analýza / formální obsahová analýza / kvantitativní obsahová analýza. Antropowebzin, (6)2, 95-99.

Elo, S., \& Kyngäs, H. (2008). The qualitative content analysis process. Journal of Advanced Nursing, 62(1), 107-115.

Forman, J., \& Damschroder, L. (2008). Qualitative content analysis. In L. Jacoby \& L. A. Siminoff (Eds.), Empirical methods for bioethics: A primer. Advances in bioethics (s. 39-62). Oxford: Elsevier.

Franzosi, R. (2007). Content analysis: Objective, systematic, and quantitative description of content. Dostupné z http://scholar.google.com/citations?view_op=view_citation\&hl=sk\& user=I5SYOqoAAAAJ\&citation_for_view=I5SYOqoAAAAJ:0EnyYjriUFMC

Glaser, B., \& Strauss, A. (1967). The discovery of grounded theory. Strategies for qualitative research. Chicago: Aldin.

Guest, G., MacQueen, K. M., \& Namey, E. E. (2012). Applied thematic analysis. Los Angeles: SAGE. Hloušková, L. (2013). Informální učení v kariéře žen. Pedagogická orientace, 23(3), 342-363.

Holsti, O. R. (1969). Content analysis for the social sciences and humanities. Reading: AddisonWesley.

Hübelová, D. (2009). Výukové metody a styly učitelů zeměpisu: případové (video) studie. Pedagogická orientace, 19(3), 53-57.

Kostková, K. (2013). K rozvoji interkulturní komunikační kompetence studentů učitelství anglického jazyka. Pedagogická orientace, 23(1), 72-91.

Krippendorff, K. (2004). Content analysis. An introduction to its methodology. Thousand Oaks: SAGE publications.

Lincoln, Y. S., \& Guba, E. G. (1985). Naturalistic inquiry. Newbury Park: SAGE.

Manganello, J., Franzini, A., \& Jordan, A. (2008). Sampling television programs for content analysis of sex on TV: How many episodes are enough? Journal of Sex Research, 45(1), 9-16.

Mayring, P. (2000). Qualitative content analysis. Forum Qualitative Sozialforschung / Forum: Qualitative Social Research, 1(2), Art. 20. Dostupné z http://nbn-resolving.de/ urn:nbn:de:0114-fqs0002204 
Mayring, P. (2014). Qualitative content analysis. Theoretical foundation, basic procedures and software solution. Klagenfurt. Dostupné $\mathrm{z}$ http://nbn-resolving.de/urn:nbn:de:0168ssoar-395173

Moretti, F., van Vliet, L., Bensing, J., Deledda, G., Mazzi, M., Rimondini, M., ... Fletcher, I. (2011). A standardized approach to qualitative content analysis of focus group discussions from different countries. Patient Education and Counseling, 82(3), 420-428.

Najvar, P., Najvarová, V., Janík, T., \& Šebestová, S. (2011). Videostudie v pedagogickém výzkumu. Brno: Paido.

Neuendorf, K. A. (2002). The content analysis guidebook. Thousand Oaks: SAGE.

Neuendorf, K. A. (2011). Content analysis - a methodological primer for gender research. Sex Roles, 64(3-4), 276-289.

Novotný, P. (2007). Psaní napříč kvalitativním výzkumem. In R. Švaříček \& K. Šed’ová (Eds.), Kvalitativní výzkum v pedagogických vědách (s. 248-258). Praha: Portál.

Popping, R. (2000). Computer-assisted text analysis. London: SAGE.

Pravdová, B. (2013). Já jako učitelka: profesní sebepojetí studentky učitelství v posledním ročníku pregraduální př́ípravy. Pedagogická orientace, 23(2), 179-194.

Richards, L. (2009). Handling qualitative data. Los Angeles: SAGE.

Roberts, C. W. (2009). Text analysis for the social sciences. New York: Routledge.

Shapiro, G., \& Markoff, J. (2009). A matter of definition. In C. W. Roberts (Ed.), Text analysis for the social sciences (s. 9-31). New York: Routledge.

Schreier, M. (2012). Qualitative content analysis in practice. London: SAGE.

Strauss, A., \& Corbinová, J. (1999). Základy kvalitativního výzkumu. Boskovice: Nakladatelství Albert.

Syslová, Z., \& Najvarová, V. (2012). Předškolní vzdělávání v České republice pohledem pedagogického výzkumu. Pedagogická orientace, 22(4), 490-515.

Šed'ová, K., \& Švaříček, R. (2013). Jak psát kvalitativně orientované výzkumné studie. Kvalita v pedagogickém výzkumu. Pedagogická orientace, 23(4), 478-510.

Švaříček, R., \& Šed'ová, K. (2007). Technika audit kolegů. In R. Švaříček \& K. Šed'ová (Eds.), Učební materiály pro kvalitativní výzkum v pedagogice (s. 62-75). Brno: Masarykova univerzita,

Vávrová, S., \& Gavora, P. (2015). Comparison of self-regulation in children and adolescents in children's home and protective educational facility. Procedia-Social and Behavioral Sciences, 174, 2524-2531.

Walsh, B. A., \& Petty, K. (2007). Frequency of six early childhood education approaches: A 10year content analysis of Early Childhood Education Journal. Early Childhood Education Journal, 34(5), 301-305.

White, M. D., \& Marsh, E. E. (2006). Content analysis: A flexible methodology. Library Trends, 55(1), 22-45.

\section{Autor}

Prof. PhDr. Peter Gavora, CSc., Univerzita Tomáše Bati ve Zlíně, Fakulta humanitních studií, Centrum výzkumu, Mostní 5139, 76001 Zlín, e-mail: gavora@fhs.utb.cz 


\title{
Content analysis in educational research: A review of the current forms
}

\begin{abstract}
A range of methodological influences caused that content analysis obtained various forms and that its current concept is complicated. The aim of this methodological paper is to describe its current forms as identified in relevant literature. In the chapters of the paper, constitutive components of content analysis are characterized. These components are as follows: types of content, types of sampling, depth of analysis, direction of analysis, types of control of coding, and modes of presentation of findings. The paper shows how these components are manifested and how they relate. The main conclusion of the paper is confirmation of inadequacy of division of content analysis into two counterparts, quantitative and qualitative. Rather it is worthwhile to assess the specific manifestation of constitutive components in each study in which content analysis was used.
\end{abstract}

Keywords: content analysis, text, manifest content, latent content, induction, deduction, reliability, credibility

Stuchlíková, I., Janík, T., et al. (2015). Oborové didaktiky: vývoj - stav - perspektivy. Brno: MU.

Oborové didaktiky jsou vědními disciplínami zaměřenými na oborově specifickou dimenzi vyučování a učení ve škole i mimo ni. Jejich agenda sahá od vymezování a zdůvodňování cílů oborového vyučování a učení přes výběr, legitimizaci a didaktickou transformaci obsahů až k metodické strukturaci učebních procesů. Problémem českého školství je, že oborové didaktiky u nás nebyly po dlouhou dobu s náležitými nároky systematicky pěstovány. Přesto se rozvinuly do podoby relativně svébytných vědních disciplín, jak o tom svědčí tato kniha. Jejím cílem je podat pohled na vývoj a stav oborových didaktik v České republice a naznačit perspektivy jejich dalšího směřování. 